\title{
PRÓBA REORGANIZACJI SIATKI PARAFII RZYMSKOKATOLICKICH W LUBLINIE W LATACH 1864-1866
}

\section{Wstęp}

Dociekania historyczne skupiają się na ogół na zbadaniu zaistniałych w przeszłości faktów i wydarzeń, ich przyczyn, przebiegu i skutków. Wydaje się jednak zasadne, by przynajmniej w niektórych przypadkach, zatrzymać się także nad koncepcjami, które zajmowały myśli ludzi w przeszłości, a które nie doczekały się realizacji. Potrzeba pochylenia się nad tego typu zagadnieniami wynika z kilku powodów. Po pierwsze niezrealizowane plany są przyczynkiem do badań nad postaciami lub instytucjami, ponieważ ukazują cele, jakie sobie stawiali i potrzeby, które te cele generowały. Dzięki takim studiom można poznać ówczesnych nie tylko z perspektywy tego, co zrobili, ale także tego, co zrobić chcieli, a co $\mathrm{z}$ rożnych powodów się nie udało. Po drugie niezrealizowane plany to świadectwo realiów epoki. To właśnie one często decydowały o tym, że dana koncepcja ostatecznie nie uzyskała aprobaty i nie weszła w życie. $Z$ tych właśnie powodów należy przyjrzeć się nieudanej próbie powiększenia liczby parafii w Lublinie, jaka miała miejsce w latach 60. XIX w.

Artykuł ma za zadanie przedstawić w sposób możliwie najpełniejszy próbę reorganizacji siatki parafialnej Kościoła rzymskokatolickiego w Lublinie, jaką podjęły władze diecezji lubelskiej. Polegała ona w pierwszej kolejności na wydzieleniu z parafii katedralnej kolejnych dwóch parafii oraz na przeniesieniu nabożeństwa parafialnego z kościoła św. Mikołaja do świątyni św. Agnieszki. Z tej racji, że nowe parafie miały powstać w kościołach po skasowanych klasztorach: bernardynach i kapucynach, stąd też początek tych planów ściśle wiązał się z się z supresją klasztorów w Królestwie Polskim w 1864 r. Końcową cezurę artykułu wyznacza zaś data roczna 1866, kiedy to wysiłki administracji diecezji ukierunkowane na utworzenie nowych parafii ustały.

*Jakub Rożek - mgr lic. teologii, doktorant w Instytucie Historii Kościoła i Patrologii KUL, e-mail: jakubrozek@outlook.com 
Temat ten, mimo dobrze zachowanej bazy źródłowej, był dotąd poruszany w opracowaniach albo w sposób bardzo ogólny ${ }^{1}$, albo jedynie fragmentaryczny ${ }^{2}$. Jeśli chodzi o wykorzystane źródła, to stanowią je głównie listy z teczki zatytułowanej „Akta dotyczące parafii po suprymowanych klasztorach”, która znajduje się w Archiwum Archidiecezjalnym Lubelskim³. Ponadto przy opracowaniu tematu pomocne były inne dokumenty z tego archiwum dotyczące m.in. kościołów poklasztornych.

Pod względem strukturalnym artykuł przedstawia plan powiększenia liczby lubelskich parafii w sposób chronologiczny poczynając od przyczyn, przez kolejne pomysły na nowe parafie, aż do ostatecznych rozstrzygnięć. Wyjątkiem w tym układzie jest początkowe omówienie źródła podstawowego do tego artykułu, co wydaje się zasadne, ponieważ wprowadza w kulisy negocjacji między władzą kościelną a organami państwowymi.

\section{1. „Akta dotyczące parafii po suprymowanych klasztorach”}

Dokumenty, które znajdują się w poszycie składają się niejako z dwóch części, które nie są w zasadzie ze sobą merytorycznie powiązane. Pierwsza przedstawia inwentarz biblioteki kościoła marianów w Skórcu ${ }^{4}$. To, co ewentualnie łączy go z drugą częścią dokumentów, to fakt, że klasztor w Skórcu także został skasowany w 1864 r. ${ }^{5} \mathrm{~W}$ drugiej natomiast znajduje się bogata korespondencja władz diecezji lubelskiej z różnymi podmiotami, która jest właściwym źródłem do niniejszej pracy. W skład tej korespondencji wchodzi dziewiętnaście listów, dwa koncepty listów zapisane na marginesach oraz protokół delegacji ds. zbadania stanu lubelskich parafii, który był załącznikiem do jednego z pism. Same listy można podzielić według kryteriów autorstwa lub treści. Przyjmując kryterium autorstwa należy stwierdzić, że w teczce znaleźć można listy zarówno strony kościelnej, jak i państwowej. Wśród korespondencji strony kościelnej znajduje się siedem listów i dwa koncepty listów autorstwa administratora diecezji lubelskiej ks. Kazimierza Sosnowskiego. Odbiorcami jego pism byli: dyrektor Komisji Rządowej Spraw Wewnętrznych i Duchownych (KRSWiD) Włodzimierz Czerkaski (trzy listy), wydział wyznań KRSWiD (jeden list i jeden koncept), gubernator lubelski Michał Buckowski (dwa listy i jeden koncept) i ks. Franciszek Szydoczyński (jeden list). Ponadto wśród nadawców ze strony kościelnej wymienić należy Konsystorz Generalny Lubelski (dwa listy: jeden do ks. Marcina Stefańskiego dziekana dekanatu tarnogrodzkiego, drugi do magistratu miasta Lublina), dziekanów tarnogrodzkiego ks. Marcina Stefańskiego i urzędowskiego ks. Leona

${ }^{1}$ J. Kumor-Mielnik, Sieć dekanalna i parafialna (archi)diecezji lubelskiej w latach 1805-2005, Lublin 2011, s. 190-194.

${ }^{2}$ J. Rożek, Dzieje parafii pw. św. Agnieszki w Lublinie w latach 1866-1939, Lublin 2013, s. 15 26 (mps Archiwum KUL).

${ }^{3}$ Archiwum Archidiecezjalne Lubelskie (dalej: AAL), sygn. Rep 60 IVA 32.

${ }^{4}$ AAL, sygn. Rep 60 IVA 32, Regestr wszelkich ksiąg znajdujących się w bibliotece klasztoru skórzeckiego, k. 1-24.

${ }^{5}$ S. Gajewski, Kasata klasztorów w diecezji lubelskiej w roku 1864, „Roczniki Humanistyczne", 21 (1973) z. 2, s. 383. 
Rządkowskiego (każdy napisał jedno pismo do Konsystorza) oraz administratora parafii Kraśnik ks. Leona Kaszewskiego, który napisał jeden list do ks. Sosnowskiego. Z kolei ze strony państwowej nadawcami pism byli: dyrektor KRSWiD Włodzimierz Czerkaski (trzy listy do administratora diecezji lubelskiej) i wydział wyznań KRSWiD (jeden list do administratora diecezji), gubernator lubelski (dwa listy do ks. Sosnowskiego, z czego jeden z załącznikiem w postaci raportu delegacji ds. zbadania stanu lubelskich kościołów) i magistrat miasta Lublina (jedno pismo do Konsystorza).

Z kolei, jeśli wziąć pod uwagę kryterium przedmiotu korespondencji, to wyróżnić można dwa wątki: opieki nad parafiami pozakonnymi poza Lublinem oraz tworzenie nowych placówek duszpasterskich w mieście. Bezpośrednio o parafiach poza Lublinem mówi siedem listów i jeden koncept, natomiast o tych w Lublinie dziesięć listów i także jeden koncept. Ponadto w aktach znajdują się dwa listy, które poruszają obydwa zagadnienia.

Listy są dobrze zachowane, a ich forma ukazuje skomplikowaną rzeczywistość, jaka nastała w Królestwie Polskim po powstaniu styczniowym. Dowodem tego jest fakt, że listy dyrektora KRSWiD są pisane równocześnie w dwóch językach: polskim i rosyjskim. Na przestrzeni kilku kolejnych lat (szczególnie 1868-1869) rząd rosyjski wdrożył prawo nakazujące korespondować z władzami świeckimi tylko w języku rosyjskim ${ }^{6}$.

Mówiąc o listach warto pokrótce przedstawić, kim byli ich adresaci i odbiorcy. W tym wypadku jednak zasadnym wydaje się skupić przede wszystkim na głównych aktorach sporu o zmianę siatki parafii w Lublinie tzn. ks. Sosnkowskim i Włodzimierzu Czerkaskim. Wiąże się to z dwoma kwestiami. Po pierwsze zarówno ze strony kościelnej, jak i państwowej były to osoby, które miały moc decyzyjną $\mathrm{w}$ sprawie reorganizacji życia parafialnego. Po drugie, to głównie między tymi dwoma czynnikami przebiegała cała dyskusja, natomiast reszta listów służyła załatwianiu spraw wynikłych z korespondencji ks. Sosnowskiego z dyrektorem KRSWiD.

Diecezja lubelska przez niemal cały okres rozbiorowy miała problem z obsadą funkcji biskupa, co wynikało z nieprzychylnego stanowiska władz zaborczych wobec Kościoła katolickiego ${ }^{7}$. W takich wypadkach ciężar rządów w diecezji spadał zwykle na wybranego tymczasowo administratora. W latach 1863-1869 administratorem diecezji lubelskiej był ks. Kazimierz Sosnowski. Urodził się na początku marca 1800 r. w Lublinie. Święcenia otrzymał w 1822 r., po czym został skierowany na dalsze studia do Krakowa. Po powrocie do Lublina pełnił różne funkcje w diecezji, zaś po śmierci biskupa lubelskiego Wincentego a Paulo Pieńkowskiego w 1863 r. został administratorem diecezji. W wyniku konfliktu z władzą rosyjską ustąpił ze stanowiska i wyjechał z Królestwa Polskiego. Zmarł w 1874 r. we Lwowie. Mimo, że na biografię ks. Sosnowskiego padają drobne cienie (podpisanie wiernopoddańczego listu do cara Aleksandra II po powsta-

${ }^{6} \mathrm{~W}$. Jemielity, Język rosyjski $w$ instytucjach kościelnych po powstaniu styczniowym, „Prawo Kanoniczne", 42 (1999) nr 1-2, s. 209-210.

${ }^{7}$ M.T. Zahajkiewicz, Centralne urzędy i instytucje diecezjalne, w: Dzieje archidiecezji lubelskiej (1805-2005), red. M.T. Zahajkiewicz, Lublin 2005, s. 52. 
niu styczniowym), to należy stwierdzić, że przez większość swojego życia prezentował ugruntowaną postawę patriotyczną i prokościelną .

$\mathrm{Z}$ racji tego, że $\mathrm{W}$ omawianym okresie na czele komórki administracyjnej odpowiadającej za sprawy wyznań, czyli KRSWiD, stał Włodzimierz Czerkaski (1824-1878), to on był drugą stroną sporu9. Do Królestwa Polskiego przybył razem z Mikołajem Milutinem w październiku 1863 r. ${ }^{10}$ Znany był ze swojego antykościelnego nastawienia - nim objął posadę dyrektora KRSWiD piastował funkcję przewodniczącego komisji zajmującej się projektem kasaty klasztorów. Prawdopodobnie planował także likwidację archidiecezji warszawskiej ${ }^{11}$. Warto wspomnieć także o samej KRSWiD. W Królestwie Polskim sprawy wyznaniowe dosyć często były przesuwane z jednego organu administracyjnego, do innego. Po powstaniu styczniowym władze carskie podjęły szeroko zakrojone działania zmierzające do likwidacji odrębności Królestwa Polskiego. W ten proces wpisała się także stopniowa reorganizacja komisji rządowych, której ostatecznym celem było podporządkowanie spraw załatwianych przez dane wydziały organom administracyjnym w Petersburgu. Nie inaczej rzecz miała się ze sprawami Kościoła katolickiego. Bezpośrednio przed 1864 r. sprawy Kościoła załatwiane były w Komisji Rządowej Wyznań Religijnych i Oświecenia Publicznego. Dnia 8 listopada 1864 r. ogłoszony został ukaz carski, na mocy którego sprawy wyznaniowe włączono do wydziału Spraw Wewnętrznych i w ten sposób powstała KRSWiD ${ }^{12}$. Działania wspomnianej komisji nie trwały długo, bowiem w marcu 1867 r. władza rosyjska rozpoczęła likwidację KRSWiD (a więc niewiele ponad dwa lata po utworzeniu), do czego ostatecznie doprowadzono 13 stycznia 1868 r. Sprawy wyznaniowe trafiły wtedy do Zarządu Spraw Duchownych Obcych Wyznań w Królestwie Polskim, a w 1871 r. zostały podporządkowane jednemu z departamentów Ministerstwa Spraw Wewnętrznych w Petersburgu ${ }^{13}$.

\section{Przyczyny podjęcia próby reorganizacji siatki parafialnej}

Starania skierowane ku zreorganizowaniu życia parafialnego w Lublinie w omawianym czasie swoją genezą sięgają represji, które spadły na Królestwo Polskie po powstaniu styczniowym. Z racji tego, że w wydarzeniach z lat 18631864 czynny udział brała także część duchowieństwa, także na Kościele kon-

${ }^{8}$ E. Walewander, Sosnowski Kazimierz, w: Encyklopedia katolicka, t. 18, red. E. Gigilewicz, kol. 620; B. Kumor, Sosnowski Kazimierz Walerian, w: Polski Słownik Biograficzny, t. 40, red. H. Markiewicz, s. 572-575; Z. Starnawski, Kazimierz Sosnowski 1800-1874, administrator diecezji lubelskiej 1863-1869, „Wiadomości Diecezjalne Lubelskie”, 59 (1985), s. 121-124.

${ }^{9}$ K. Morawska, Centralne władze wyznaniowe Królestwa Polskiego, w: Archiwum Główne Akt Dawnych w Warszawie. Przewodnik po zespole, t. 2, red. F. Ramotowska, Warszawa 1998, s. 198.

${ }_{10}$ P.P. Gach, Kasaty zakonów na ziemiach dawnej Rzeczypospolitej i Ślaska, Lublin 1984, s. 176.

${ }^{11}$ Gajewski, Kasata, s. 357.

${ }^{12}$ G. Smyk, Administracja publiczna Królestwa Polskiego w latach 1864-1915, Lublin 2011, s. 235; Morawska, Centralne władze, s. 185. Natomiast Gajewski w cytowanym artykule podaje, że KRSWiD została utworzona 8 lipca 1864 r., zob. Gajewski, Kasata, s. 357.

${ }^{13}$ Smyk, Administracja publiczna, s. 239-240. 
centrowały się prześladowania ze strony władzy świeckiej. Prostą konsekwencją represji stała się próba zmodyfikowania dotychczasowych rozwiązań w duszpasterstwie.

\section{a. Sytuacja Kościoła w Lublinie po listopadzie 1864 r.}

Władza carska zauważywszy, jak znaczącą rolę odgrywali zakonnicy zarówno podczas manifestacji patriotycznych w latach 1861-1862, jak i w czasie powstania styczniowego postanowiła położyć kres ich działalności. W tym celu, w pierwszej połowie 1864 r. Mikołaj Milutin opracował szkic projektu, który zakładał skasowanie klasztorów w Królestwie Polskim ${ }^{14}$. Po wstępnej aprobacie cara Aleksandra II w czerwcu 1864 r. prace nad ostateczną wersją projektu przejęła specjalna komisja z Włodzimierzem Czerkaskim na czele. Komisja pracowała od 10 lipca do 19 sierpnia, a następnie przesłała gotowy projekt ukazu carowi ${ }^{15}$. Ten go zaakceptował i podpisał 8 listopada $1864 \mathrm{r} .^{16} \mathrm{Na}$ mocy tego dokumentu, w nocy z 27 na 28 listopada 1864 r. w całym Królestwie Polskim zlikwidowano 109 klasztorów, a tylko 35 pozwolono legalnie funkcjonować (tzw. klasztory etatowe). Ukaz zakładał także istnienie tzw. klasztorów nieetatowych, które nie ulegały natychmiastowej likwidacji, lecz miały zostać skasowane w dłuższej perspektywie czasowej ${ }^{17}$. Przy każdym skasowanym kościele władza cywilna zostawiała od jednego do trzech zakonników, by ci opiekowali się zabudowaniami i dbali, by nabożeństwo nie ustawało ${ }^{18}$. Oczywiście liczba ta była niewystarczająca, by dobrze sprawować te obowiązki. Resztę zakonników wywożono do klasztorów etatowych.

Kasata miała brzemienne skutki dla Królestwa Polskiego, w tym i dla społeczności lokalnych, takich jak lubelska. W samym mieście w nocy z 27 na 28 listopada skasowano klasztory: bernardynów przy kościele Nawrócenia św. Pawła, kapucynów przy kościele św. Piotra i Pawła, augustianów przy kościele św. Agnieszki, karmelitów bosych przy kościele św. Józefa. Pozostały natomiast wizytki i bernardynki jako klasztory nieetatowe oraz dominikanie na Starym Mieście jako placówka etatowa ${ }^{19}$.

Likwidacja tylu klasztorów wpłynęła znacząco na kwestię duszpasterstwa w Lublinie, bowiem do tej pory zakony były bardzo aktywne na tym polu. Można tu powołać się na kilka przykładów. Kapucyni lubelscy od początku przybycia do miasta w XVIII w., aż do kasaty prowadzili regularne duszpasterstwo wynikające $\mathrm{z}$ roku liturgicznego ${ }^{20}$ oraz pomagali w okolicznych parafiach m.in. przez posługe

${ }^{14}$ Gach, Kasaty, s. 176-177.

${ }^{15}$ Gajewski, Kasata, s. 357-358.

${ }^{16}$ Dziennik Praw Królestwa Polskiego, t. 62, Warszawa 1864, s. 407-419.

${ }^{17}$ R. Prejs, Zakonnicy franciszkańscy Królestwa Polskiego po kasacie 1864 roku. Dzieje-postawy, Warszawa 2003, s. 90-91; Gajewski, Kasata, s. 359-360.

${ }^{18}$ W. Wójcik, Tak zwana reforma klasztorów w 1864 roku na terenie diecezji sandomierskiej, „Archiwa, Biblioteki i Muzea Kościelne”, 23 (1971), s. 355.

${ }^{19}$ Gajewski, Kasata, s. 388.

${ }^{20}$ M. Budziarek, Kapucyni w Lublinie. Dzieje klasztoru 1721-1864, Warszawa-Lublin 1996, s. 126-127. 
kaznodziejską i spowiedź2 ${ }^{2}$. Dodać do tego także można coroczne wielkie obchody ku czci św. Feliksa, który był patronem dzieci. Uroczystości z okazji jego święta przyciągały wielu wiernych, szczególnie matki z dziećmi ${ }^{22}$. Zresztą wierni przy okazji wszystkich nabożeństw chętnie odwiedzali świątynię kapucynów. Nie inaczej było w przypadku duszpasterstwa prowadzonego przez bernardynów w kościele Nawrócenia św. Pawła. Także ten kościół cieszył się dużą popularnością wśród wiernych ze względu na liczne bractwa prowadzone przez zakonników ${ }^{23}$ i kult św. Antoniego ${ }^{24}$. Nadto trzeba pamiętać, że było normą, że wielu wiernych na co dzień i w niedziele uczęszczało do kościołów zakonnych, zamiast do parafii, co wynikało z bliskości zamieszkania przy tych świątyniach i z uroczystego sposobu sprawowania liturgii przez zakonników ${ }^{25}$.

W obliczu kasaty stało się jasne, że całość pasterskiej troski o wiernych spocznie na kapłanach z dwóch istniejących w mieście parafii. Pierwsza z nich, to parafia katedralna - liczyła w tamtym okresie 9.238 wiernych, których obsługiwało 6 księży. Druga parafia zlokalizowana była przy kościele św. Mikołaja na Czwartku. Pracował tam tylko jeden ksiądz, który pełnił posługę dla 3.375 wiernych $^{26}$. Księża diecezjalni nie mogli liczyć na pomoc duszpasterską dominikanów, którzy pozostali w mieście, gdyż ci dostali zakaz np. spowiadania w okresie przedświątecznym poza swoim kościołem ${ }^{27}$. Dodać do tego należy fakt, że obie parafie były rozległe terytorialnie i oprócz dystryktów miejskich w ich granice wchodziły także podlubelskie wioski. Dlatego też duszpasterzom pod względem posługi, a wiernym pod względem uczestnictwa w nabożeństwach było trudniej bez posługi zakonników.

Kasata klasztorów w Królestwie Polskim w 1864 r. spowodowała znaczący brak w Kościele m.in. na płaszczyźnie duszpasterstwa. Zdecydowanie należało więc dołożyć wysiłku, aby tę lukę zapełnić, a jednym z pomysłów było tworzenie parafii w pozakonnych klasztorach. Taką próbę podjęła władza diecezjalna $\mathrm{w}$ Lublinie, ale także i w innych miastach. Przykładem może być Warszawa, gdzie w tym samym czasie na skutek starań, władza rosyjska pozwoliła na utworzenie 8 nowych placówek ${ }^{28}$.

${ }^{21}$ Tamże, s. 160-161, 164-165.

${ }^{22}$ AAL, sygn. Rep 60 IVA 32, Protokół delegacji ds. zbadania stanu lubelskich parafii z 20 czerwca 1865 r., k. $63 \mathrm{v}$.

${ }^{23}$ J.A. Wadowski, Kościoły lubelskie, Lublin 2004, s. 551-557.

${ }^{24}$ A. Chadam, Lublin, w: Klasztory bernardyńskie w Polsce w jej granicach historycznych, red. H.E. Wyczawski, Kalwaria Zebrzydowska 1985, s. 189-190.

${ }^{25}$ Gajewski, Kasata, s. 376.

${ }^{26}$ AAL, sygn. Rep 60 IVA 32, Protokół delegacji ds. zbadania stanu lubelskich parafii z 20 czerwca 1865 r., k. $60 \mathrm{v}$.

${ }^{27}$ AAL, sygn. Rep 60 XI 33, List KRSWiD do ks. Kazimierza Sosnowskiego z 7 października $1865 \mathrm{r}$

${ }^{28}$ B. Kumor, Ustrój i organizacja Kościoła polskiego w okresie niewoli narodowej (17721918), Kraków 1980, s. 697. 


\section{b. Sprawa parafii pozakonnych poza Lublinem}

Po wykonaniu ukazu kasacyjnego w listopadzie 1864 r. administrator diecezji lubelskiej ks. Kazimierz Sosnowski rozpoczął proces zbierania informacji o sytuacji parafii po skasowanych klasztorach położonych na terenie diecezji. W omawianym przypadku chodziło o sześć kościołów: pijarów w Chełmie, misjonarzy w Dysie, franciszkanów w Górecku i Puszczy Solskiej (dziś: Biłgoraj), kanoników regularnych w Kraśniku i dominikanów w Krasnobrodzie. Administrator diecezji chciał dowiedzieć się przede wszystkim ilu zakonników pozostało w klasztorach, co to za ludzie i czy są kompetentni do prowadzenia ksiąg stanu cywilnego ${ }^{29}$. W tym celu rozesłał pisma z zadaniem zebrania tych informacji do dziekanów. Ogólny wniosek, jaki nasuwał się po dokonaniu tego rozeznania był raczej negatywny dla zakonników, przez co administrator diecezji nie brał ich pod uwagę przy obsadzeniu wspomnianych parafii (z wyjątkiem Chełma i Dysa ${ }^{30}$. Ks. Sosnowski wystosował więc 1 grudnia 1864 r. pismo do dyrektora KRSWiD, w którym poprosił o fundusze dla proboszcza, wikariuszy i służby kościelnej w wyżej wspomnianych parafiach pozakonnych ${ }^{31}$. Innymi słowy chciał, aby dawniejsze parafie zakonne istniały dalej, z przyznanymi etatami, tym razem jednak prowadzone przez księży diecezjalnych lub ewentualnie zakonników.

Czerkaski odpowiedział administratorowi diecezji 12 grudnia, prosząc go, by doprecyzował, w których parafiach mają zostać zakonnicy, do których zaś pragnie skierować księży diecezjalnych. Ponadto dyrektor Komisji przykazał ks. Sosnowskiemu, by księża mający trafić na parafię byli „,poważni i zupełnie godni tako pod względem moralnym, jako też politycznym"32. Wydawało się, że sprawa zostanie sprawnie załatwiona, gdyż administrator diecezji odpowiedział na pismo dyrektora KRSWiD już 19 grudnia. Przedstawił w swoim liście liczebność parafian należących do poszczególnych placówek pozakonnych, plan dotyczący liczby duszpasterzy w poszczególnych parafiach i listę tymczasowo mianowanych administratorów w parafiach pozakonnych. Niestety w materiałach źródłowych brak dokumentu odpowiedzi KRSWiD. W sprawie wspomnianych parafii pozakonnych w teczce „Akta dotyczące parafii po suprymowanych klasztorach" pojawiają się bowiem jeszcze tylko trzy listy i jeden koncept listu, które dotyczą kwestii braku pensji dla ks. Leona Kaszewskiego (administratora parafii Kraśnik) ${ }^{33}$. Niemniej jednak ostatecznie wspomniane wyżej parafie przeszły w zarząd diecezji, jednak sytuacja w najbliższych latach po kasacie nie była kom-

${ }^{29}$ AAL, sygn. Rep 60 IVA 32, List Konsystorza Generalnego Diecezji Lubelskiej do dziekana tarnogrodzkiego ks. Marcina Stefańskiego z 30 listopada 1864 r., k. 27r-v.

${ }^{30}$ Gajewski, Kasata, s. 375.

${ }^{31}$ AAL, sygn. Rep 60 IVA 32, List ks. Kazimierza Sosnowskiego do Włodzimierza Czerkaskiego z 1 grudnia 1864 r., k. 25v.

${ }^{32}$ Tamże, List Włodzimierza Czerkaskiego do ks. Kazimierza Sosnowskiego z 12 grudnia 1864 r., k. 33 r.

${ }^{33}$ Tamże, List ks. Leona Kaszewskiego do ks. Kazimierza Sosnowskiego z 13 czerwca 1865 r., k. 55r-v; List ks. Kazimierza Sosnowskiego do KRSWiD z dnia 21 czerwca 1865 r., k. 56r-v; List KRSWiD do ks. Kazimierza Sosnowskiego z dnia 18 września 1865 r., k. 57r; Koncept odpowiedzi ks. Kazimierza Sosnowskiego na marginesie listu KRSWiD z 25 września 1865 r., k. 57r. 
fortowa. Pozakonne parafie prowadzone były przez administratorów, co było wygodne dla rządu, bowiem nie trzeba było utrzymywać proboszcza oraz wikariuszy. Z drugiej strony było to trudne dla Kościoła, bowiem często dochodziło do konfliktów między mianowanymi przez ks. Sosnowskiego administratorami parafii, a pozostałymi w nich zakonnikami ${ }^{34}$.

Sprawa placówek pozakonnych na terenie diecezji przyczyniła się wszakże do powstania projektu poszerzenia liczby parafii w Lublinie. Bezpośrednim impulsem do tego była, nietypowa jak na organy rządowe, propozycja dyrektora KRSWiD. We wspomnianym liście z 12 grudnia 1864 r. Włodzimierz Czerkaski komentując sprawę parafii pozakonnych poza Lublinem zwrócił się do ks. Sosnowskiego:

Przy tem znajduję potrzebę zwrócić szczególną uwagę J[aśnie] W[ielmożnego] Pana i na kościoły parafialne w samym Lublinie, o których J[aśnie] W[ielmożny] Pan nie raczyłeś wspomnieć,

po czym dodał:

Obecnie po zniesieniu i zamknięciu w Lublinie klasztorów męskich, przedstawia się, jak sądzę, najdogodniejsza sposobność przy zamienieniu niektórych poklasztornych kościołów na świeckie parafialne, usunąć obecny dla mieszkańców Lublina brak kościołów parafialnych. W tym przedmiocie będę zarówno oczekiwał wniosków J[aśnie] W[ielmożnego] Pana i mogę go zapewnić, że rząd tak zawsze dbający o dobry stan kościołów rzymskokatolickich w Królestwie, pokaże czynem i w obecnym razie całą troskliwość swoją o religijne potrzeby narodu ${ }^{35}$.

Innymi słowy, to dyrektor KRSWiD zaproponował utworzenie nowych parafii w Lublinie. Taka sytuacja była niezwykle komfortowa dla ks. Sosnowskiego. Dzięki temu, że to strona rządowa wyszła jako pierwsza z pomysłem utworzenia nowych parafii w Lublinie administrator diecezji lubelskiej zdobywał mocną kartę przetargową w dyskusjach z KRSWiD. W każdej bowiem chwili, kiedy Komisja z Czerkaskim na czele chciałaby utrudniać powstanie nowych parafii ks. Sosnowski mógł powoływać się na powyższą deklarację i oczekiwać od KRSWiD konsekwencji w jej realizacji. Jak pokazał późniejszy bieg wydarzeń, nie raz wykorzystywał ten atut ${ }^{36}$.

Należy dodać, że nic nie wskazuje na to, by ks. Sosnowski sam szykował podobną inicjatywę. Można wnosić o tym na podstawie kilku przesłanek. Po pierwsze brak zachowanych jakichkolwiek źródeł, które mogłyby sugerować pomysł administratora na nowe parafie po kasacie. Po drugie klimat popowstaniowych prześladowań nie sprzyjał negocjacjom z rządem. Po trzecie Kościół w Królestwie Polskim był raczej prześladowany, niż wspierany rządowymi etatami. Widać

${ }^{34}$ Gajewski, Kasata, s. 376.

${ }^{35}$ AAL, sygn. Rep 60 IVA 32, List Włodzimierza Czerkaskiego do ks. Kazimierza Sosnowskiego z dnia 12 grudnia 1864 r., k. 33v-34v.

${ }^{36}$ Tamże, List ks. Kazimierza Sosnowskiego do ks. Franciszka Szydoczyńskiego z 4 kwietnia 1865 r., k. 53 r.; List ks. Kazimierza Sosnowskiego do Michała Buckowskiego z 25 października 1865 r., k. 70v; List ks. Kazimierza Sosnowskiego do Michała Buckowskiego z 19 lipca 1866 r., k. $78 \mathrm{r}$. 
to na przykładzie diecezji lubelskiej. Od momentu jej powstania w $1805 \mathrm{r}$. do $1865 \mathrm{r}$. na całym jej obszarze powstały tylko 3 nowe parafie ${ }^{37}$, czego ks. Sosnowski musiał mieć świadomość. Te czynniki świadczą zarówno o tym, że administrator diecezji nie brał, przynajmniej do tego okresu, pod uwagę nowej organizacji parafialnej w Lublinie, jak i o tym, że inicjatywa, z którą wyszedł dyrektor KRSWiD pochodziła w zupełności od strony rządowej. Trudno jednak ustalić przyczynę tej niespodziewanej hojności. Nie wydaje się prawdopodobne, że wyniknęła ona ze wzmiankowanego wcześniej faktu tzn. dawniejsza Komisja Spraw Wewnętrznych dopiero od miesiąca zajmowała się sprawami wyznaniowymi. W związku z tym mogły im się zdarzyć pewne pochopne (z perspektywy polityki Królestwa Polskiego) decyzje. Tę tezę należy odrzucić, gdyż propozycję nowych parafii wysunął Czerkaski, który miał jasny, negatywny stosunek do Kościoła. Należy jednak zauważyć, że list dyrektora KRSWiD z nietypową propozycją datowany jest na 12 grudnia, czyli 2 tygodnie po dokonanej kasacie. Nie jest tajemnicą, że Milutin, Czerkaski i namiestnik Królestwa Polskiego Fiodor Berg planując likwidację klasztorów obawiali się, że ludzie zareagują antyrządowymi manifestacjami na taki proceder ${ }^{38}$. Być może w propozycji Czerkaskiego z 12 grudnia dalej pobrzmiewały echa tej obawy i postanowił dać społeczeństwu w zamian za skasowane klasztory coś, co uciszyłoby negatywne głosy ludzi. Mogło być też tak, że dyrektor KRSWiD dostał już kilka próśb od biskupów z Królestwa Polskiego $\mathrm{w}$ sprawie tworzenia parafii $\mathrm{w}$ pozakonnych świątyniach i postanowił ubiec podobną prośbę ks. Sosnowskiego pokazując tym samym, jak bardzo rząd troszczy się o Kościół.

\section{Etapy negocjacji w sprawie reorganizacji siatki parafialnej}

Podjęta próba zmian w siatce parafii w Lublinie obejmowała dosyć długie negocjacje władz diecezji lubelskiej z państwowymi organami. Rozpoczęły się one W grudniu 1864 r. przedstawieniem przez ks. Sosnowskiego projektu reorganizacji parafii w mieście, następnie dotyczyły m.in. utworzenia specjalnej delegacji, która miała zbadać sprawę, a zakończyły się w październiku 1866 r. ostateczną decyzją KRSWiD.

\section{a. Założenia projektu}

Pierwszym krokiem administratora diecezji lubelskiej w kierunku utworzenia nowych parafii w Lublinie było odbycie narady z duchowieństwem katedralnym. Zebranie odbyło się 15 grudnia 1864 r. i dotyczyło kwestii, w jaki sposób najlepiej podzielić parafię katedralną, z pożytkiem dla wiernych. Niestety brak jest protokołu $\mathrm{z}$ tego zebrania, zaś ono samo wzmiankowane jest w dokumentacji tylko dwa razy ${ }^{39}$. Wspomnienie jednak o tej naradzie jest o tyle ważne, że to na niej powstał projekt poszerzenia siatki parafialnej w Lublinie o dwie nowe parafie.

${ }^{37}$ Kumor-Mielnik, Sieć dekanalna, s. 178.

${ }^{38}$ Gajewski, Kasata, s. 367.

${ }^{39}$ AAL, sygn. Rep 60 IVA 32, List Konsystorza Generalnego Diecezji Lubelskiej do Magistratu miasta Lublin z 16 grudnia 1864 r., k. 35r.; List ks. Kazimierza Sosnowskiego do Michała Buckowskiego z 25 października 1865 r., k. 71r. 
Gotowy projekt został przez władzę diecezjalną przedstawiony najpierw 16 grudnia magistratowi lubelskiemu ${ }^{40}$, zaś 19 grudnia dyrektorowi KRSWiD ${ }^{41}$. W przypadku pisma do magistratu plan tam zawarty nie był szczegółowy. Administratorowi diecezji chodziło przede wszystkim, by ratusz przesłał mu statystyki dotyczące liczby ludności poszczególnych wsi wokoło Lublina, które miały wchodzić w skład nowych parafii, gdyż statystyki te były niezbędne w przedłożeniu planu KRSWiD. Prezentacja projektu magistratowi odbyła się więc przy okazji prośby o dane. Władze miejskie zwlekały jednak z podaniem wymaganych statystyk i stąd ks. Sosnowski dopiero 4 stycznia dostarczył Czerkaskiemu uzupełnienie projektu w postaci liczby ludności nowych parafii ${ }^{42}$. Te trzy pisma dają wspólnie ogólny ogląd, na czym w zasadzie polegać miał projekt administratora diecezji lubelskiej.

Sam plan miał trzy zasadnicze założenia. Po pierwsze z parafii katedralnej należało wydzielić dwie nowe parafie i ulokować je przy kościołach pozakonnych - kapucynów i bernardynów ${ }^{43}$. Po tym zabiegu w granicach parafii katedralnej miało pozostać 5.227 wiernych zamieszkałych na terenie: Starego Miasta oraz ulic: Podwale, Królewska, Świętoduska, Zielona, Żmigród, Krakowskie Przedmieście aż do muru przy byłym kościele kapucynów i ul. Poczętkowskiej (dziś: Staszica). Przy katedrze, według projektu, miało pracować sześciu wikariuszy (czyli bez zmian), jednak ks. Sosnowski wnosił o podwyżkę dla nich ze 135 rubli do 270 rubli rocznie. Do parafii przy kościele pokapucyńskim należeć miała ul. Krakowskie Przedmieście (od ul. Poczękowskiej do końca), miasteczko Wieniawa oraz wsie: Czechówka Dolna, Czechów, Sławinek, Sławin, Wola Sławinkowska, Dąbrowica, Płouszowice. Na tym terenie katolików z miasta było 347, zaś ze wsi 1.315 w sumie więc parafia miała liczyć 1.662 parafian, dla których posługę duszpasterską mieli sprawować proboszcz i dwaj wikariusze. Wynagrodzenie, jakie proponował dla nich ks. Sosnowski w swym projekcie, to 750 rubli dla proboszcza i 225 dla wikariuszy. W skład ostatniej planowanej parafii - pobernardyńskiej - wchodzić miały ulice: Namiestnikowska (dziś: Narutowicza), Bernardyńska, Dolna Panny Marii, wsie: Rury, Wrotków, Bronowice, oraz przedmieście Piaski. Te z kolei tereny zamieszkiwało 2.513 osób, w tym katolików: z miasta 1.430 , zaś ze wsi 1.083 . Także w tym przypadku administrator diecezji proponował dla

${ }^{40}$ Tamże, List Konsystorza Generalnego Diecezji Lubelskiej do Magistratu miasta Lublin z 16 grudnia 1864 r., k. 35r-36r.

${ }^{41}$ Tamże, List ks. Kazimierza Sosnowskiego do Włodzimierza Czerkaskiego z 19 grudnia 1864 r., k. $37 \mathrm{r}-42 \mathrm{v}$.

${ }^{42}$ Tamże, List ks. Kazimierza Sosnowskiego do Włodzimierza Czerkaskiego z 4 stycznia 1865 r., k. $44 \mathrm{r}$

${ }^{43}$ Tamże, List Konsystorza Generalnego Diecezji Lubelskiej do Magistratu miasta Lublin z 16 grudnia 1864 r., k. 35r; List ks. Kazimierza Sosnowskiego do Włodzimierza Czerkaskiego z 19 grudnia 1864 r., k. 40v, 41v; List ks. Kazimierza Sosnowskiego do Włodzimierza Czerkaskiego z 4 stycznia 1865 r. k. 44r. Ślady tego planu odnaleźć można także w: Archiwum Państwowe w Lublinie (APL), sygn. 35/22/0/4.7.1.2/2372, List ks. Kazimierza Sosnowskiego do Prezydenta miasta Lublina Aleksandra Dylewskiego z 15 lutego 1865 r.; List Prezydenta miasta Lublina Aleksandra Dylewskiego do Michała Buckowskiego z 19 lutego 1865 r. 
parafii proboszcza i dwóch wikariuszy z takimi samymi płacami, jak w przypadku kościoła pokapucyńkiego. Ponadto dwie nowe parafie musiały zatrudniać, także na koszt państwa, służbę kościelną w postaci m.in. organistów i zakrystianów, dla których projekt zakładał pensje w wysokości 150 rubli rocznie.

Drugi punkt projektu związanego z lubelskimi parafiami dotyczył parafii św. Mikołaja. Według ustaleń ks. Sosnowskiego miała ona pozostać w swych dawnych granicach terytorialnych jednak z innym ośrodkiem kultu. Administrator diecezji planował bowiem, aby przenieść nabożeństwo z kościoła św. Mikołaja na Czwartku do kościoła św. Agnieszki na Kalinowszczyźnie ${ }^{44}$. Powodem takiej decyzji był fakt, że kościół na Czwartku był otoczony domostwami Żydów, których obecność nie pozwala jakoby godnie odbywać niektórych nabożeństw. Oczywiście ks. Sosnowski zaznaczył w swym liście do KRSWiD, że taka zamiana będzie wiązać się z kosztami wynikającymi z potrzeby remontu klasztoru poaugustiańskiego, gdzie w założeniu mieli mieszkać kapłani i służba kościelna. Dodatkowo administrator prosił, by przydzielić proboszczowi tej parafii wikariusza. Ogólna ludność tej parafii, miała wynosić 3.233 wiernych, w tym z miasta 1.115 (ulice wokół wzgórza Czwartek i na Kalinowszczyźnie) i wiejskiej 2.118 (wsie głównie od wschodniej strony Lublina).

Ostatni punkt planu ks. Sosnowskiego dotyczył kościoła Świętego Ducha na Krakowskim Przedmieściu. Administrator diecezji zaznaczył w liście do Czerkaskiego, że nie był to nigdy kościół parafialny i nie ma środków ani potrzeby, aby takim był. Nie zmienia to jednak faktu, że ludzie cały czas do niego uczęszczają i warto byłoby, aby nabożeństwo tam nie ustawało. Warto byłoby więc uzyskać fundusze dla księdza, który troszczyłby się o kult w tym kościele przynajmniej w święta ${ }^{45}$.

Jak wynika z powyższego ks. Sosnowski z pomocą duchowieństwa katedralnego ułożył zwarty i logicznie umotywowany plan restrukturyzacji lubelskiej sieci parafialnej. W swojej koncepcji kierował się chęcią zniwelowania negatywnych skutków kasaty klasztorów na płaszczyźnie duszpasterstwa oraz innych niedogodności, z którymi musieli się borykać wierni i duszpasterze parafialni. Trzeba także pamiętać, że nie każdy z punktów w powyższym planie był tak samo ważny dla administratora. W świetle jego korespondencji wydaje się, że priorytetem było utworzenie nowych parafii, na drugim miejscu zaś stawiał konieczność przeniesienia nabożeństwa z wzgórza Czwartek na Kalinowszczyznę. Natomiast zabiegi o zapewnienie ciągłości kultu przy kościele Świętego Ducha odbywały się raczej przy okazji powyższych starań. Temu bowiem zagadnieniu ks. Sosnowski poświęcił najmniej uwagi.

Warto zastanowić się także nad perspektywami realizacji tego planu tzn. na ile realne było wdrożenie w życie koncepcji ks. Sosnowskiego. Poza wspomnianą wcześniej ogólną nieprzychylnością władz Królestwa Polskiego do Kościoła, która sugerowała negatywne rozpatrzenie sprawy (mimo inicjatywy KRSWiD), możliwość powstania nowych parafii warunkował jeszcze jeden czynnik - liczba

${ }^{44}$ AAL, sygn. Rep 60 IVA 32, List ks. Kazimierza Sosnowskiego do Włodzimierza Czerkaskiego z 19 grudnia 1864 r., k. 40r-v.

${ }^{45}$ Tamże, k. 41r. 
wiernych. Poza archidiecezją warszawską parafie, które liczyły ponad 10 tysięcy wiernych należały do rzadkości - np. w diecezji lubelskiej takich w ogóle nie było. Pod względem liczby katolików parafie lubelskie nie wyróżniały się więc zbytnio, a raczej wpisywały w średnią. Zdecydowanie ponad średnią były parafie ulokowane w Warszawie, które liczyły od 12 do 30 tysięcy wiernych ${ }^{46}$. Skoro więc większość parafii w państwie funkcjonowała w podobnym modelu co lubelskie i władza ich nie dzieliła, stąd plan ks. Sosnowskiego nie rokował pomyślnie na przyszłość.

\section{b. Wątpliwości KRSWiD}

Dyrektor KRSWiD odpowiedział na pismo administratora diecezji lubelskiej dopiero 30 marca $1865 \mathrm{r}^{47}$ zgłaszając cały szereg zastrzeżeń do proponowanych przez ks. Sosnowskiego zmian. Nic nie wskazuje na to, by wcześniej odbywała się jakakolwiek korespondencja, ponieważ powyższe pismo Czerkaskiego powołuje się tylko na dotąd wspomniane listy i nie wymienia żadnych nowych.

Pierwsza wątpliwość władzy rządowej dotyczyła liczby ludności poszczególnych parafii. Z pisma wynika, że dyrektor KRSWiD oprócz danych, które podał mu administrator diecezji miał wgląd także do innych wykazów, które podawały odmienne wyliczenia. Według planu ks. Sosnowskiego ogólna liczba parafian wynosiła 12.635, natomiast KRSWiD sięgnęła także do rubryceli diecezji za $1864 \mathrm{r}$., według której ta liczba to 13.233 , oraz do danych magistratu miasta i naczelnika powiatu lubelskiego, które przedstawiały liczbę niższą tj. 10.517 wiernych. Trzeba wspomnieć, że administrator diecezji także opierał się na wyliczeniach magistratu, ale tylko jeśli chodzi o ludność wiejską, tutaj natomiast magistrat musiał podać także swoje wyliczenia odnośnie do katolików w samym Lublinie. W związku z tym brakiem precyzji dyrektor KRSWiD oświadczył, że trzeba tę liczbę zweryfikować i gdyby okazała się ona niższa niż wyliczenia z rubryceli należałoby utworzyć nie dwie nowe parafie, a tylko jedną ${ }^{48}$.

Kolejna wątpliwość dotyczyła możliwości utworzenia parafii w kościele po kapucynach. Według Czekaskiego klasztor po zakonnikach był zbyt duży tylko dla proboszcza, wikariuszy i służby kościelnej. Co więcej, gdyby tam zamieszkali, to rząd nie byłby w stanie dobrze zagospodarować reszty klasztoru na użytek publiczny ${ }^{49}$. Wynika z tego, że władza cywilna chciała w całości przejąć na skarb państwa klasztor, by w późniejszym okresie wykorzystać go na cele rządowe lub społeczne. Trzecie zastrzeżenie zasygnalizowane w piśmie dotyczyło przenosin nabożeństwa parafialnego z kościoła św. Mikołaja do kościoła św. Agnieszki. Ks. Sosnowski formułując plan reorganizacji parafii w Lublinie ten punkt podpierał argumentem o bliskości zabudowań żydowskich. Dyrektor KRSWiD ustalił,

${ }^{46}$ Kumor, Ustrój i organizacja, s. 692.

${ }^{47}$ AAL, sygn. Rep 60 IVA 32, List Włodzimierza Czerkaskiego do ks. Kazimierza Sosnowskiego z 30 marca 1865 r., 45r-51r.

${ }^{48}$ Tamże, $46 \mathrm{v}-47 \mathrm{v}$.

${ }^{49}$ Tamże, $48 \mathrm{v}-49 \mathrm{r}$. 
że kościół św. Agnieszki, podobnie jak św. Mikołaja także jest nimi otoczony. W związku z tym powstawało pytanie, czemu miałaby służyć taka zamiana ${ }^{50}$.

Należy w tym miejscu zastanowić się nad słusznością zastrzeżeń Czerkaskiego. Przez ich pryzmat widać bowiem wyraźnie zmianę nastawienia dyrektora Komisji do współpracy z ks. Sosnowskim w sprawie zadośćuczynienia potrzebom duszpasterskim Lublina. Pierwsza uwaga dotycząca braku zgodności w liczbie wiernych była słuszna, jednak ewidentnie skierowana na z góry założony cel tzn. zminimalizowania liczby nowych parafii, a nie dojście prawdy. Jasnym jest, że cel ten nie szedł $\mathrm{w}$ parze $\mathrm{z}$ troską o religijne potrzeby wiernych, natomiast był na rękę skarbowi państwa, który w ten sposób mógł zaoszczędzić na etatach. Podobnie było w przypadku zastrzeżeń odnośnie do utworzenia parafii w kościele po kapucynach. Dyrektor KRSWiD formułując je, nie krył się ze swoimi zamiarami wykorzystania klasztoru w innym celu, niż mieszkanie proboszcza, wikariuszy i służby kościelnej. Oznaczało to, że miał inne plany niż tworzenie nowej parafii. Najbardziej zrozumiałe były zastrzeżenia dotyczące kościoła św. Agnieszki, bowiem w świetle wiadomości posiadanych przez Komisję i jej dyrektora przeniesienie tam nabożeństwa faktycznie mogło wydać się bezzasadne. Wątpliwość ta została wyjaśniona na dalszym etapie negocjacji, jakkolwiek trudno nie przypuszczać, że i w tym przypadku stanowiskiem Czerkaskiego kierował interes władzy świeckiej, który dążył do ograniczenia wydatków na Kościół.

\section{c. Delegacja ds. zbadania stanu lubelskich parafii}

Włodzimierz Czerkaski oprócz zgłoszenia powyższych zastrzeżeń wskazał w liście z 30 marca drogę do ich rozwiązania. Rozkazał powołać delegację ds. zbadania stanu lubelskich parafii, aby rozwiać wspomniane wątpliwości. W jej skład miało wchodzić sześciu członków: dwóch powołanych przez administratora diecezji, dwóch powołanych przez gubernatora lubelskiego i dwóch występujących z ramienia magistratu miasta Lublin. Organizację delegacji dyrektor KRSWiD polecił gubernatorowi Michałowi Buckowskiemu. Delegacja, po zakończeniu prac miała przedstawić ich wyniki gubernatorowi, a ten z kolei magistratowi i administratorowi diecezji, by ci zgłosili swoje uwagi. Protokół z uwagami miał być następnie przesłany do KRSWiD ${ }^{51}$.

Po rozkazie Czerkaskiego gubernator lubelski sprawnie rozpoczął organizację delegacji, gdyż już 3 kwietnia 1865 r. wysłał do ks. Sosnowskiego pismo $\mathrm{z}$ prośbą o wyznaczenie członków delegacji ze strony kościelnej ${ }^{52}$. W liście tym zaznaczył, że taka sama prośba trafiła już do magistratu oraz wymienił swoich delegatów. Byli nimi Antoni Szmidt (naczelnik Sekcji Dóbr i Lasów) i Józef Buchaczkowski (adiunkt Rządu Guberialnego). W odpowiedzi na pismo gubernatora ks. Sosnowski ze swojej strony na delegatów mianował kanonika katedry lubelskiej ks. Franciszka Szydoczyńskiego i wikariusza parafii katedralnej ks. Henryka

50 Tamże, 48r-v.

51 Tamże, k. 45v-46r, 49v-50v.

52 Tamże, List Michała Buckowskiego do ks. Kazimierza Sosnowskiego z 3 kwietnia 1865 r., k. 52r-v. 
Kowalskiego ${ }^{53}$. Z kolei delegatami z ramienia magistratu miasta Lublina zostali Antoni Czerwiński piastujący urząd radnego lubelskiego magistratu i sekretarz magistratu Józef Jezierski ${ }^{54}$. Najpóźniej swoich przedstawicieli powołał magistrat, ponieważ uczynił to 6 kwietnia $1865 \mathrm{r}$.

$\mathrm{W}$ związku z desygnowaniem delegatów warto wspomnieć o jeszcze jednej kwestii. W teczce „Akta dotyczące parafii po suprymowanych klasztorach” zachował się list ks. Sosnowskiego do ks. Szydoczyńskiego, który zawierał wytyczne dla kościelnych przedstawicieli ${ }^{55}$. Po pierwsze powinni oni podkreślać, że pomysł powiększenia siatki lubelskich parafii wyszedł od dyrektora KRSWiD, a nie od strony kościelnej. Skoro jednak władza rządowa nie chce przystać na propozycję administratora diecezji, to ks. Sosnowski nie widzi potrzeby wzniecania sporu i zaakceptuje, by w Lublinie powstała tylko jedna nowa parafia pod warunkiem jednak, że powstanie przy kościele po kapucynach. Kościół ten bowiem miał najlepszą lokalizację dla wiernych mieszkających we wsiach za rogatkami warszawskimi. Drugi punkt wskazany przez administratora diecezji, o którego realizację szczególnie mieli zabiegać delegaci, dotyczył przenosin nabożeństwa z kościoła św. Mikołaja, do kościoła św. Agnieszki. Ks. Sosnowski podkreślił, że te przenosiny były konieczne ze względu na dobro wiernych z rejonów wiejskich, którym bliżej było do kościoła na Kalinowszczyźnie. Jak widać administrator diecezji zmienił w tym miejscu argumentację w kwestii przenosin nabożeństwa tym razem nie chodziło o negatywny wpływ zabudowań żydowskich, a o komfort wiernych wynikający z dobrej lokalizacji kościoła św. Agnieszki.

Trudno ustalić, jakie były kroki delegacji po jej wyłonieniu. Wspomniano wyżej, że wszyscy delegaci byli już na pewno ustanowieni 6 marca. Kolejnym zachowanym dokumentem w tej sprawie jest protokół ze spotkania delegacji datowany na 20 czerwca 1865 r. Protokół ten został wysłany administratorowi diecezji przez gubernatora lubelskiego 19 października ${ }^{56}$ i w swej treści nie wspominał wprost, by delegaci spotkali się gdzieś między 6 marca a 20 czerwca. Jednakże dokument podaje, że przedstawiciele trzech wspomnianych stron dogłębnie badali i analizowali sprawę sytuacji Kościoła w Lublinie ${ }^{57}$. Na tej podstawie należy wnioskować, że ostateczny protokół został poprzedzony przynajmniej kilkoma spotkaniami delegatów, które miały charakter zarówno wspólnych dyskusji, jak też wizji lokalnej. Co zaś tyczy się samego protokołu, to jest on zachowany w bardzo dobrym stanie i wydaje się opracowany rzetelnie. Wyróżnić można w nim zasadnicze części: wstęp, w którym delegaci powołują się na pismo

${ }^{53}$ Tamże, Koncept listu ks. Kazimierza Sosnowskiego do Michała Buckowskiego z 4 kwietnia 1865 r., k. 52r; List ks. Kazimierza Sosnowskiego do ks. Franciszka Szydoczyńskiego z 4 kwietnia 1865 r., k. 53 r.

${ }^{54}$ Tamże, Protokół delegacji ds. zbadania stanu lubelskich parafii z 20 czerwca 1865 r., k. 59r.

${ }^{55}$ Tamże, List ks. Kazimierza Sosnowskiego do ks. Franciszka Szydoczyńskiego z 4 kwietnia 1865 r., k. 53r-54r.

${ }^{56}$ Tamże, List Michała Buckowskiego do ks. Sosnowskiego z 19 października 1865 r., k. 58r; Protokół delegacji ds. zbadania stanu lubelskich parafii z 20 czerwca 1865 r., k. 59r-69r.

${ }^{57}$ Tamże, Protokół delegacji ds. zbadania stanu lubelskich parafii z 20 czerwca 1865 r., k. 62r, $65 \mathrm{r}$. 
dyrektora KRSWiD z 30 marca 1865 r., jako na podstawę prawną swojego działania, część pierwszą, w której odpowiadają na wątpliwości KRSWiD i część drugą, w której konstruują pomysł reorganizacji parafii w Lublinie. Nie zachowały się jednak żadne przesłanki, czy finalny protokół był dziełem kolegialnym wszystkich członków delegacji, czy może któryś z nich miał zdanie decydujące. $Z$ racji tego, że protokół poruszał w swojej treści sprawy wielu lubelskich kościołów może służyć za dobre uzupełnienie w badaniach historycznych dotyczących lubelskich świątyń.

Delegacja w sporządzonym protokole zawarła odpowiedzi na wszystkie wątpliwości, jakie miał dyrektor KRSWiD. Po pierwsze faktyczną liczbę katolików w Lublinie i 22 wioskach wokoło miasta ustalono na 12.613. Liczba ta rozkładała się nierównomiernie na dwie parafie: katedralną z ludnością miejską 6.170 i ze wsi 3.068 (w sumie 9.238 wiernych) i św. Mikołaja z wiernymi z terenów Lublina w liczbie 1.308 i z wiosek za rogatką łęczyńską w liczbie 2.067 (w sumie 3.375 wiernych $)^{58}$.

Delegaci jasno stwierdzili, że parafia katedralna musi zostać podzielona. W tym celu przeanalizowali i zbadali sytuację lubelskich kościołów, by ustalić które $\mathrm{z}$ nich najlepiej nadają się na ośrodek parafialny. W granicach miasta znajdowało się ówcześnie 13 kościołów, jednak części z nich nie można było brać pod uwagę w projekcie. Należały do nich cztery kościoły zgromadzeń zakonnych żeńskich i męskich, a także kościół przy szpitalu Jana Bożego i seminaryjny. Odliczając jeszcze dwa kościoły parafialne pozostawało pięć świątyń, które delegacja szczegółowo przebadała pod kątem przydatności na parafię. Pierwszym z nich był kościół Świętego Ducha. Oceniono go jednak jako nieprzydatny w realizacji projektu, ponieważ był za mały, jak na parafię, oraz potrzebował solidnego remontu ${ }^{59}$. Co ciekawe wzmianka o potrzebie renowacji stoi niejako w sprzeczności z faktem, że stosunkowo niedawno tj. w połowie XIX w. kościół takową przeszedł ${ }^{60}$. Drugi kościół, któremu przyjrzała się delegacja, był świątynią należącą przed kasatą do karmelitów. Także i w tym przypadku opinia była negatywna, a umotywowanie podobne: kościół był mały i w złym stanie. Ponadto zwrócono uwagę, że jego lokalizacja nie była dogodna dla wiernych. Poruszono także kwestię karmelitańskiego klasztoru - on także wymagał odrestaurowania, jednak kwota takiego remontu byłaby bardzo wysoka ${ }^{61}$. Trzeci kościół, o którym mowa w protokole, to kościół św. Agnieszki, po augustianach. Oceniono go bardzo dobrze, jako potencjalny ośrodek parafialny, choć zwrócono także uwagę, że kościół znajdował się ówcześnie poza ścisłymi granicami Lublina ${ }^{62}$. Kolejny omówiony kościół, to świątynia po bernardynach. Według delegatów był obszerny i w bardzo dobrym stanie, ponieważ na początku lat 60 . XIX w. przeszedł gruntowny remont. Do tego miał dogodną lokalizację, zaś wierni z jego

${ }^{58}$ Tamże, k. 61r-v.

${ }^{59}$ Tamże, k. 62 r.

${ }^{60}$ Wadowski, Kościoty, s. 402.

${ }^{61}$ AAL, sygn. Rep 60 IVA 32, Protokół delegacji ds. zbadania stanu lubelskich parafii z 20 czerwca 1865 r., k. $62 \mathrm{v}$.

${ }^{62}$ Tamże, k. 62v, 64r-v. 
okolic nieprzerwanie brali udział w odprawianych tam nabożeństwach ${ }^{63}$. Ostatnią świątynią przedstawioną przez delegację, był kościół po zakonie kapucynów. Ocena i motywacja delegatów w tym przypadku była taka sama jak w przypadku świątyni po bernardynach z tą różnicą, że kościół kapucynów był mniejszy. Jednakże ostatecznie uznali, że zarówno ten, jak i dwa poprzednie kościoły spełniają wszystkie wymogi kościołów parafialnych ${ }^{64}$.

Kolejna wątpliwość dyrektora KRSWiD dotyczyła sprawy konieczności przenosin nabożeństwa parafialnego ze świątyni na Czwartku do kościoła św. Agnieszki. Według badań delegacji nie było żadnych przesłanek, aby pozostawić parafię przy kościele św. Mikołaja. Był on bowiem w złym stanie i mógł pomieścić maksymalnie 280 osób. Odnośnie do lokalizacji, to znajdował się na stromym zboczu, które się obsypywało oraz prowadziła do niego gliniana droga, którą trudno było przejść w porze deszczowej. Ponadto w bliskości kościoła było wielu Żydów - protokół podaje, że na 1.062 mieszkańców wzgórza Czwartek było ich 698 - którzy zanieczyszczali cmentarz oraz byli przeszkodą w odprawianiu publicznych nabożeństw. Zupełnym przeciwieństwem tego stanu była świątynia po augustianach na Kalinowszczyźnie. Klasztor i kościół były w dobrym stanie, $\mathrm{z}$ wygodą drogą i mógł pomieścić nawet 600 wiernych. Jeśli chodzi o Żydów, to ich liczbę szacowano na 619, przy ogólnej liczbie ludności przedmieścia Kalinowszczyzna 917. W tym przypadku jednak delegacja nie widziała w ich obecności problemu, zwracała natomiast uwagę, że jest ich de facto mniej niż na Czwartku ${ }^{65}$.

Ostatnią wątpliwością podnoszoną przez Włodzimierza Czerkaskiego była sprawa klasztoru przy kościele po kapucynach na ul. Krakowskie Przedmieście. Był on zbudowany $\mathrm{w}$ czworobok, $\mathrm{z}$ czego jednym bokiem złączony był z kościołem, z którego można było przejść do pomieszczeń gospodarczych. Natomiast dwie części klasztoru, tj. frontowa i od podwórza miały osobne wejścia. W związku z tym delegacja sugerowała, że gdyby tworzyć parafię, to nie byłoby problemu zaadaptować na potrzeby społeczne części klasztoru z osobnymi wejściami, a dwie pozostałe oddać duchowieństwu ${ }^{66}$.

Kolejna część protokołu przedstawiała najlepsze według delegatów rozwiązanie sprawy lubelskich parafii. Przede wszystkim postulowali, aby przenieść nabożeństwo z kościoła św. Mikołaja na Kalinowszczyznę przy jednoczesnym niezmienianiu granic tej parafii. Po drugie delegacja zaznaczyła, że każdy podział parafii katedralnej jest pożądany, jednak trzeba brać pod uwagę zamożność parafian, gdyż to na ich barki spadnie utrzymanie kościoła. W związku z tym, że nie są to ludzie na ogół zamożni projekt zakładał tylko jedną nową parafię, która winna powstać przy kościele po bernardynach. Co ciekawe delegacja zaznaczyła, że ta parafia mogłaby nosić wezwanie św. Antoniego, a nie Nawrócenia św. Pawła ${ }^{67}$. Dokładny plan, wraz z podziałem na ulice przedstawia poniższa tabela:

\footnotetext{
${ }^{63}$ Tamże, k. 62v-63r.

${ }^{64}$ Tamże, k. 63r-v.

${ }^{65}$ Tamże, k. 63v-64v.

66 Tamże, k. 64v-65r.

${ }^{67}$ Tamże, k. 65r-66v.
} 
Tabela nr 1. Proponowany podział lubelskich parafii

\begin{tabular}{|c|c|c|c|c|c|c|c|c|}
\hline \multicolumn{3}{|c|}{ Katedralna } & \multicolumn{3}{|c|}{ Pobernardyńska } & \multicolumn{3}{|c|}{ Poaugustiańska } \\
\hline Ulice & Wsie & Wierni & Ulice & Wsie & Wierni & Ulice & Wsie & Wierni \\
\hline Grodzka & & 874 & $\begin{array}{l}\text { Namiestni- } \\
\text { kowska }\end{array}$ & & 172 & Czwartek & & 364 \\
\hline Rybna & & 246 & $\begin{array}{l}\text { Panny } \\
\text { Marii }\end{array}$ & & 679 & $\begin{array}{l}\text { Kalinow- } \\
\text { szczyzna }\end{array}$ & & 308 \\
\hline Olejna & & 81 & $\begin{array}{l}\text { Bernardyń- } \\
\text { ska }\end{array}$ & & 164 & $\begin{array}{l}\text { S i e r a - } \\
\text { kowszczy- } \\
\text { zna }\end{array}$ & & 230 \\
\hline Rynek & & 482 & Przechodnia & & 56 & $\begin{array}{l}\text { Probo- } \\
\text { stwo }\end{array}$ & & 208 \\
\hline Jezuicka & & 217 & $\begin{array}{l}\text { Wizytkow- } \\
\text { ska }\end{array}$ & & 141 & $\begin{array}{l}\text { Lubartow- } \\
\text { ska }\end{array}$ & & 178 \\
\hline Zlota & & 201 & Pijarska & & 94 & Rzeźnicza & & 20 \\
\hline Podwale & & 169 & $\begin{array}{l}\text { Poczętkow- } \\
\text { ska }\end{array}$ & & 51 & Ruska & & \\
\hline $\begin{array}{l}\text { Królew- } \\
\text { ska }\end{array}$ & & 199 & Wieniawska & & 76 & & Tatary & 309 \\
\hline Nowa & & 259 & Czechowska & & 89 & & Biskupie & 260 \\
\hline $\begin{array}{l}\text { Ś w i ę to - } \\
\text { duska }\end{array}$ & & 173 & $\begin{array}{l}\text { Krakowskie } \\
\text { Przedmie- } \\
\text { ście }\end{array}$ & & 341 & & $\begin{array}{l}\text { Jakubowi- } \\
\text { ce Muro- } \\
\text { wane }\end{array}$ & 116 \\
\hline Zielona & & 27 & & $\begin{array}{l}\text { Wieniawa z } \\
\text { Czechówką } \\
\text { Dolną } \\
\end{array}$ & 940 & & $\begin{array}{l}\text { Ś w i d n i - } \\
\text { czek z Za- } \\
\text { dubiem }\end{array}$ & 161 \\
\hline Żmigród & & 127 & & Czechów & 153 & & $\begin{array}{l}\text { Ś w i d n i - } \\
\text { czek Duży } \\
\text { i Mały }\end{array}$ & 625 \\
\hline $\begin{array}{l}\text { Krakow- } \\
\text { skie Przed- } \\
\text { mieście }\end{array}$ & & 547 & & Sławinek & 127 & & Wólka & 55 \\
\hline Zamkowa & & 59 & & Snopków & 190 & & Trześniów & \\
\hline $\begin{array}{l}\text { Domini- } \\
\text { kańska }\end{array}$ & & 134 & & Sławin & 162 & & Hajdów & 153 \\
\hline $\begin{array}{l}\text { Archidia- } \\
\text { końska }\end{array}$ & & 124 & & $\begin{array}{l}\text { Wola Sła- } \\
\text { winkowska }\end{array}$ & 50 & & Rudnik & 130 \\
\hline Bramowa & & 107 & & $\begin{array}{l}\text { D ą b r o w a } \\
\text { i Połuszo- } \\
\text { wice }\end{array}$ & 408 & & $\begin{array}{l}\text { Czechów- } \\
\text { ka Górna }\end{array}$ & 145 \\
\hline $\begin{array}{l}\text { Trynitar- } \\
\text { ska }\end{array}$ & & 100 & & Rury & 457 & & $\begin{array}{l}\text { Lemszczy- } \\
\text { zna }\end{array}$ & 108 \\
\hline & Bronowice & 35 & & & & & & \\
\hline & Wrotków & 552 & & & & & & \\
\hline & $\begin{array}{l}\text { Przedmie- } \\
\text { ście Piaski }\end{array}$ & 129 & & & & & & \\
\hline
\end{tabular}

Źródło: AAL, sygn. Rep 60 IVA 32, Protokół delegacji ds. zbadania stanu lubelskich parafii z 20 czerwca 1865 r., k. 68r-69r. 
Jak widać na podstawie powyższej tabeli do parafii katedralnej po podziale miało należeć 18 ulic i 3 wsie. Ludność miejska należąca do tej parafii wynosić miała 4.115, zaś wiejska 717 wiernych, co dawało w sumie 4.832 katolików. Jeśli chodzi o drugą parafię - pobernardyńską, to według projektu należeć miała do niej ludność z 11 ulic Lublina, gdzie mieszkało 1.925 wiernych. Ponadto w skład tej parafii wchodziła także ludność wiejska z 10 wsi, której liczba w sumie wynosiła 2.481. Oznaczało to, że nowopowstała parafia w kościele pobernardyńskim miała liczyć w sumie 4.406 wiernych. Ostatnia z parafii wymienionych w tabeli nie zmieniła co prawda swoich granic, jednak warto wspomnieć, że w jej skład wchodziło 7 ulic zamieszkanych przez 1.308 wiernych, oraz 12 wsi w których żyło 2.067 katolików (brak informacji jednak o ludności z ul. Ruskiej i z Trześniowa). Dawało to więc liczbę parafian 3.375. Sumując powyższe liczby wychodziło więc, że ogólna liczba wiernych należących do parafii lubelskich wynosiła 12.613 osób, w tym 7.478 ludności miejskiej i 5.135 ludności wiejskiej. W świetle tych danych widać pewną specyfikę tego planu. W wypadku jego realizacji w Lublinie istniałyby 3 parafie, zaś każda $\mathrm{z}$ nich miałaby nieco inny charakter. Katedralna byłaby parafią typowo miejską z niewielkim procentem wiernych $\mathrm{z}$ rejonów wiejskich, zaś parafia św. Agnieszki byłaby w tym względzie jej przeciwieństwem - mimo, że w jej skład wchodziły tereny miejskie, to służyłaby w większości wiernym z okolicznych wsi. Natomiast mająca powstać parafia w kościele po bernardynach łączyłaby obie te rzeczywistości.

Można tu zwrócić uwagę na jeszcze jedną sprawę. Biorąc pod uwagę stanowisko administratora diecezji, projekt delegacji wydawał się robiony nieco na przekór jego planom. Ks. Sosnowski zabiegał najpierw o dwie nowe parafie, a następnie poszedł na kompromis i był skłonny zaakceptować utworzenie tylko jednej. Oczywiście zastrzegł, że jeśli ma powstać jedna, to w kościele po kapucynach. Tymczasem delegacja nie dość, że zdecydowała się wydzielić z parafii katedralnej tylko jedną nową parafię, to ulokowała ją w kościele pobernardyńskim. W związku z tym rodzą się pytania. Należałoby zapytać o rolę ks. Szydoczyńskiego i ks. Kowalskiego w tworzeniu projektu delegacji - czy mieli cokolwiek do powiedzenia, czy z góry zostali przegłosowani? Z drugiej strony można zadać pytanie, na ile delegacja (nie licząc delegatów kościelnych) tworząc projekt nowych parafii działała celowo na przekór ks. Sosnowskiemu, a na ile kierowała się logicznymi przesłankami.

\section{c. Ustanie starań o realizację projektu}

Jak wyżej zostało wspomniane gubernator lubelski przedłożył protokół delegacji ks. Sosnowskiemu do oceny dnia 19 października 1865 r. Administrator diecezji odpowiedział Buckowskiemu w gorzkim tonie już 25 października ${ }^{68}$. Ogólnie ks. Sosnowski był zawiedziony projektem przedstawionym przez delegację. W swoim liście systematycznie ujął nieścisłości w retoryce zarówno dyrektora KRSWiD, jak i delegacji. Najpierw odniósł się do Czerkaskiego wytykając mu, że

${ }^{68}$ Tamże, List ks. Kazimierza Sosnowskiego do Michała Buckowskiego z 25 października 1865 r., k. 70r.-73r. 
z początku chciał tworzyć nowe parafie w kościołach poklasztornych, by potem ograniczyć ich potencjalną liczbę do jednej ze względu na niewystarczającą liczbę wiernych. Administrator nie wierzył, że tak niewielka różnica między stanem faktycznym w liczbie wiernych tj. 12.613 według protokołu, a domniemanym stanem z rubryceli (13.233) mogłaby być przyczyną odejścia od pomysłu dwóch nowych parafii na rzecz tylko jednej nowej placówki duszpasterskiej ${ }^{69}$. Następnie ks. Sosnowski odniósł się do argumentacji delegacji. Zauważył, że delegaci najpierw piszą, że wierni nie są wystarczająco zamożni, aby utrzymać dwie nowe parafie, a następnie proponują, aby nowa parafia powstała w większym kościele pobernardyńskim. Administrator diecezji sugeruje w związku z tym, że delegacja winna być konsekwentna i wyznaczyć na nowy ośrodek parafialny kościół po kapucynach, bo jest mniejszy i tańszy w utrzymaniu ${ }^{70}$. Ostatecznie ks. Sosnowski zdaje się zupełnie na wolę dyrektora KRSWiD i stwierdza:

(...) uważam za zbyteczne osobną dołączać opinię do projektu przez delegację zdziałanego. Wiem albowiem, że takowy projekt nie jest wyrazem bezwzględnego przekonania, a tym mniej objawem uczuć tętniących miłością religii nie powiększaną widokami materialnymi ${ }^{71}$.

Po tym liście administratora diecezji lubelskiej następuje długa przerwa w korespondencji między czynnikami kościelnymi i rządowymi w sprawie nowych parafii. Kolejny zachowany list pochodzi dopiero z 7 lipca 1866 r. (Włodzimierz Czerkaski do ks. Sosnowskiego), zaś z jego treści wiadomo, że było jeszcze przynajmniej jedno wcześniejsze pismo - 2 czerwca $1866 \mathrm{r}$. administrator diecezji pisał do KRSWiD w sprawie liczby wikariuszy w lubelskich parafiach. $\mathrm{Na}$ tej podstawie można przyjąć, że między październikiem 1865 r. a czerwcem 1866 r. sprawa nowych parafii utknęła w miejscu. Z pewnością ten zastój wynikał z pewnych procedur - KRSWiD czekała na opinię nie tylko administratora diecezji odnośnie do protokołu delegacji, ale także gubernatora lubelskiego i magistratu. Niewykluczone, że urzędnicy zwlekali z wydaniem ostatecznej decyzji w tej sprawie. Następnie projekt musiał być przeanalizowany w Warszawie w KRSWiD. Dodatkowo sprawę komplikował fakt, że 26 grudnia $1865 \mathrm{r}$. zmieniły się przepisy finansowania Kościoła katolickiego w Królestwie Polskim, co KRSWiD musiała uwzględnić. W świetle nowych przepisów de facto przestało zupełnie istnieć prawo patronatu, a w zamian większość kościelnych urzędów miała przyłączony etat, na podstawie którego państwo wypłacało określoną pensję. Dodać do tego należy, że liczba poszczególnych etatów została wyznaczona z góry dla każdej diecezji ${ }^{72}$.

Jak już zostało wspomniane, Włodzimierz Czerkaski odpowiedział 7 lipca 1866 r. na pismo administratora diecezji z 25 października 1865 r. i na propozycje zawarte $\mathrm{w}$ protokole delegacji ${ }^{73}$. Cały list ma formę dużo bardziej formalną

${ }^{69}$ Tamże, k. 71v-72r.

${ }^{70}$ Tamże, k. 73r.

${ }^{71}$ Tamże, k. 72r.

${ }^{72}$ A. Okolski, Wyktad prawa administracyjnego oraz prawa administracyjnego obowiazujacego w Królestwie Polskim, t. 2, Warszawa 1882, s. 472; Kumor, Ustrój i organizacja, s. 695.

${ }^{73}$ AAL, sygn. Rep 60 IVA 32, List Włodzimierza Czerkaskiego do ks. Sosnowskiego z 7 lipca 1866 r., k. 74r-77v. 
i chłodną niż poprzednie pisma Czerkaskiego. Dyrektor na początku pisma sugeruje, że cały konflikt rozgrywa się między ks. Sosnowskim, który proponuje cztery parafie, a gubernatorem lubelskim, który chce, by było ich trzy ${ }^{74}$. Dystansuje się tym samym od odpowiedzialności za cała sprawę i od swoich słów propozycji nowych parafii w Lublinie. W kolejnych akapitach pisma zupełnie przekreśla możliwość powstania nowych parafii, co motywuje dwoma argumentami. Po pierwsze wspomniane prawo z 26 grudnia $1865 \mathrm{r}$. nie uwzględnia nowych etatów w diecezji lubelskiej, tak więc niemożliwe było powstanie nawet jednej nowej parafii ${ }^{75}$. Po drugie dyrektor KRSWiD był zdania, że dwie dotychczasowe parafie w zupełności wystarczą dla ludności miasta i jego okolic ${ }^{76}$. Co zaś tyczy się przeniesienia nabożeństwa z kościoła św. Mikołaja, to Czerkaski był zwolennikiem tego pomysłu. Postanowił zostawić wolną rękę ks. Sosnowskiemu w wyborze kościoła, do którego winno się te parafię przenieść - sugerował pobernardyński, poaugustiański lub Świętego Ducha. W przypadku tego ostatniego zauważał, że dzięki ulokowaniu tam parafii świątynia zyskałby opiekę, o którą prosił administrator diecezji w piśmie z 19 grudnia 1864 r. Gdyby jednak kościół Świętego Ducha się nie nadawał na parafię, to żadne dodatkowe fundusze nie zostaną na niego przeznaczone. W efekcie należałoby wtedy uczynić ten kościół filialnym i od czasu do czasu wysyłać tam jednego wikariusza, aby nabożeństwo nie ustawało ${ }^{77} \mathrm{Na}$ końcu listu Czerkaski prosił ks. Sosnowskiego, aby porozmawiał z gubernatorem na powyższe tematy i zakomunikował KRSWiD ostateczne decyzje.

W omawianej teczce „Akta dotyczące parafii po suprymowanych klasztorach” zachował się jeszcze jeden list od ks. Sosnowskiego do gubernatora Buckowskiego datowany na 19 lipca $1866 \mathrm{r}^{78}$ Administrator diecezji lubelskiej nawiązał w nim do pisma Czerkaskiego z 7 lipca. Na wstępie zaznaczył, że pogodził się z faktem, że nowe parafie nie powstaną i ponadto poruszył w nim dwie zasadnicze sprawy. Pierwszą była kwestia przenosin nabożeństwa z kościoła św. Mikołaja. Kościół Świętego Ducha niezmiennie wydawał się władzy kościelnej nieodpowiedni do takiej zamiany. Natomiast kościół św. Agnieszki, nadawał się na parafię, jednak w czasie przedłużających się negocjacji z rządem, klasztor przy kościele został zajęty przez wojsko, przez co teraz wymagał sporych nakładów finansowych na niezbędny remont. W opinii administratora diecezji, aby przenieść tam parafię, państwo musiałoby wyłożyć pieniądze na ten cel. Drugą sprawą poruszoną w tym piśmie, była opieka nad kościołem Świętego Ducha. Ks. Sosnowski sugerował, że w związku ze stanowiskiem dyrektora KRSWiD należy uczynić z tej świątyni kaplicę publiczną i oddać ją pod opiekę lubelskim dominikanom, by w miarę możliwości dbali o odprawianie nabożeństw.

Zakończenie prawie dwuletnich negocjacji nastąpiło definitywnie po liście Włodzimierza Czerkaskiego z 7 lipca. Ostateczna decyzja dyrektora KRSWiD

${ }^{74}$ Tamże, k. $74 \mathrm{v}$.

${ }^{75}$ Tamże, k. 75r-v.

${ }^{76}$ Tamże, k. $75 \mathrm{v}$.

${ }^{77}$ Tamże, k. 75v-76v.

${ }^{78}$ Tamże, List ks. Kazimierza Sosnowskiego do Włodzimierza Czerkaskiego z 19 lipca 1866 r., k. 78r-v. 
była dokładnym zaprzeczeniem jego słów z grudnia 1864 r., gdy pisał o trosce, jaką rząd darzy religię katolicką w Królestwie Polskim. Cała jednak sprawa negocjacji ks. Sosnowskiego z Czerkaskim dobitnie pokazuje kilka rzeczywistości. Po pierwsze dyrektor KRSWiD nie był zainteresowany powstaniem nowych parafii. Skutecznie wymyślał więc nowe powody, by odłożyć jak najbardziej w czasie ich powstanie: najpierw poddał pod wątpliwość liczbę wiernych, potem zwołał delegację, która powołała się na argument zamożności parafian. Ostatecznie zaś przekreślił cały pomysł powołując się na nowe prawo finansowania Kościoła. Wydaje się, że gdyby nie wspomniana zmiana prawa, która nastąpiła w grudniu $1865 \mathrm{r}$. trudniej byłoby się Czerkaskiemu wycofać ze swojego pomysłu utworzenia nowych parafii. Oczywiście nie oznacza to, że pomysł doszedłby do skutku. Można mieć pewność, że nawet jeżeli wszedłby w życie, to nie w kształcie, jaki proponował ks. Sosnowski, ale co najwyżej w formie przedstawionej przez delegację ds. zbadania stanu lubelskich parafii. Drugą sprawą, która uwydatnia się po przyjrzeniu się przebiegowi negocjacji jest fakt, że Lublin po kasacie faktycznie potrzebował zapełnić lukę po zakonach. W związku z tym administrator diecezji starał się o powstanie nowych parafii, nawet mimo wyraźnej niechęci i problemów, jakie władza cywilna przed nim stawiała. Ostatecznie wykazał się sporą determinacją, która jest świadectwem potrzeby zapewnienia dobrego duszpasterstwa wiernym.

W ramach podsumowania negocjacji warto również dodać, że nie można mówić o jednym projekcie reorganizacji parafii w Lublinie w latach 1864-1866. Ks. Sosnowski miał przynajmniej dwa plany: pierwszy zakładał utworzenie dwóch nowych parafii, drugi tylko jednej w kościele po kapucynach. Ten drugi był jednak reakcją na stanowisko KRSWiD. Osobny projekt przedstawiła delegacja, która także zaproponowała tylko jedną nową parafię ale w kościele pobernardyńskim. Punktem wspólnym tych planów było założenie przeniesienia ośrodka parafialnego z kościoła św. Mikołaja do kościoła św. Agnieszki na Kalinowszczyźnie. Natomiast kwestia zagospodarowania kościoła Świętego Ducha wybrzmiała mocno tylko w liście administratora diecezji z 16 grudnia 1864 r., potem natomiast traktowana była marginalnie.

\section{Skutki próby reorganizacji siatki parafii w Lublinie}

Zasadniczą częścią planu reorganizacji parafii w Lublinie było utworzenie nowych placówek parafialnych. Z listu dyrektora KRSWiD z 7 lipca 1866 r. stało się jasne, że ta część projektu nie doczeka się realizacji. Mimo to blisko dwuletnie wysiłki ks. Sosnowskiego przyniosły zmiany na duszpasterskiej mapie Lublina.

Administrator diecezji lubelskiej na jesieni 1866 r. korespondował dalej z KRSWiD w sprawie przeniesienia nabożeństwa na Kalinowszczynę ${ }^{79}$. Finałem tych rozmów była ostateczna decyzja władz rządowych datowana na 14 grudnia 1866 r. pozwalająca na przeniesienie ośrodka parafialnego z kościoła św. Mikołaja do świątyni po zakonie augustianów ${ }^{80}$. Jeśli zaś chodzi o wymóg remontu klasz-

${ }^{79}$ AAL, sygn. Rep 60 IVB 135, List KRSWiD do ks. Kazimierza Sosnowskiego z dnia 23 września 1866 r.; List ks. Kazimierza Sosnowskiego do KRSWiD z 5 października 1866 r.

${ }^{80}$ Tamże, List KRSWiD do ks. Kazimierza Sosnowskiego z dnia 14 grudnia 1866 r. 
toru, o którym wcześniej wspominał ks. Sosnowski, to ostatecznie ciężar finansowy wzięli na siebie parafianie ${ }^{81}$. Warto też pamiętać, że decyzja KRSWiD z 14 grudnia 1866 r. nie oznaczała automatycznego przeniesienia parafii. Od tego momentu rozpoczął się proces przystosowywania kościoła św. Agnieszki i klasztoru, do sprawowania funkcji ośrodka parafialnego. Dokument erekcyjny parafii się nie zachował, zaś źródła, jak i opracowania podają wiele różnych dat powstania parafii na Kalinowszczyźnie ${ }^{82}$. Najbardziej istotne jednak są dwie daty - wspomniany 14 grudnia, gdyż wtedy ostatecznie władza rządowa zgodziła się na przeniesienie parafii. Druga data natomiast to 10 stycznia 1868 r. Wtedy bowiem zanotowany jest w księdze metrykalnej najwcześniejszy wpis, jakim był pierwszy chrzest w kościele św. Agnieszki ${ }^{83}$. Na tej podstawie można przypuszczać, że pełny proces przeniesienia parafii trwał właśnie od 14 grudnia 1866 r. do początku 1868 r., bowiem ówczesne rozumienie parafii bazowało głównie na możliwości prowadzenia ksiąg metrykalnych. Innymi słowy część projektu ks. Sosnowskiego z grudnia 1864 r. mówiąca o przeniesieniu nabożeństwa z parafii św. Mikołaja została zrealizowana, jednak trwało to stosunkowo długo, gdyż aż do stycznia $1868 \mathrm{r}$.

Do pozytywnych owoców przenosin nabożeństwa zaliczyć można z pewnością fakt odnowienia klasztoru po augustianach, zapewnienie stałej opieki świątyni na Kalinowszczyźnie oraz przybliżenie kościoła parafialnego ludności wiejskiej zza rogatki łęczyńskiej. Nie sposób jednak nie wspomnieć o negatywnym oddźwięku, jaki wywołała zmiana ośrodka parafialnego wśród części mieszkańców parafii zamieszkałych w okolicach wzgórza Czwartek. Okazało się bowiem, że dla nich zamiana kościoła parafialnego była dużą niedogodnością. Zaczęli oni zgłaszać swoje obiekcje do administratora diecezji już 27 sierpnia 1868 r. argumentując, że kościół św. Mikołaja może popaść w ruinę bez opieki. Ponadto droga wiodąca do kościoła św. Agnieszki była niewybrukowana, przez co często było tam duże błoto i mieszkańcy z okolic Czwartku mieli problem z dostaniem się na Kalinowszczynę ${ }^{84}$. W związku z tym część parafian proponowała utworzyć przy kościele św. Mikołaja filię z możliwością prowadzenia ksiąg metrykalnych. W źródłach można odnaleźć wzmianki, że przez kolejne lata mieszkańcy niezmiennie prosili władzę diecezjalną o jakieś rozwiązanie niedogodności wynikającej z przenosin nabożeństwa na Kalinowszczyznę. Proponowali np. włączenie okolic wzgórza Czwartek do parafii katedralnej ${ }^{85}$. Być może władza diecezjalna dołożyłaby większych starań w celu usunięcia wspomnianych niedogodności, jednak antykościelna polityka Królestwa Polskiego nie dawała większych szans na powodzenie ewentualnych prób. Ostatecznie jednak utworzenie filii przy ko-

${ }^{81}$ Tamże, List ks. Kazimierza Sosnowskiego do Rządu Guberialnego Lubelskiego z dnia 17 grudnia $1866 \mathrm{r}$.

${ }^{82}$ Rożek, Dzieje parafii, s. 24-26.

${ }^{83}$ APL, sygn. 35/1861/0/2.4/61, Księga urodzeń, małżeństw i zgonów, s. 2.

${ }^{84}$ AAL, sygn. Rep 60 IVB 126, List parafian z okolic wzgórza Czwartek do ks. Kazimierza Sosnowskiego z dnia 27 sierpnia $1868 \mathrm{r}$.

${ }^{85}$ Tamże, List parafian z okolic wzgórza Czwartek do Konsystorza Generalnego Lubelskiego $\mathrm{z}$ dnia 5 kwietnia $1872 \mathrm{r}$. 
ściele św. Mikołaja doszło do skutku 16 października 1902 r. ${ }^{86}$, przez co definitywnie zażegnano problem, jaki powstał po przeniesieniu parafii z Czwartku na Kalinowszczynę w $1868 \mathrm{r}$.

Sprawy związane z kościołem św. Agnieszki były w prostej linii jedynymi następstwami omawianej próby reorganizacji siatki parafialnej w Lublinie. Warto jednak przyjrzeć się jeszcze jednej kwestii, która jak się zdaje, znalazła swój początek w negocjacjach ks. Sosnowskiego z KRSWiD. Po fali represji wobec Kościoła związanej z powstaniem styczniowym, odwilż przyszła dopiero w $1905 \mathrm{r}$. w związku z ukazem tolerancyjnym. Jednak podczas tego blisko 40-letniego okresu, władza świecka czasem pozwalała Kościołowi na pewne inicjatywy. W związku z tym udało się w diecezji lubelskiej w drugiej połowie XIX w. utworzyć pięć nowych parafii (nie licząc parafii św. Agnieszki) ${ }^{87}$. Jedną z nich była parafia w Lublinie, przy kościele Nawrócenia św. Pawła, czyli w świątyni pobernardyńskiej. Została erygowana 3 maja 1884 r. przez bpa lubelskiego Kazimierza Wnorowskiego. Źródła w postaci dokumentu erekcyjnego ${ }^{88}$ parafii i inwentarza kościoła z $1885 \mathrm{r}^{89}$ wskazują, że głównym architektem planu powstania nowej placówki duszpasterskiej był bp Walenty Baranowski. Faktycznie bp Baranowski w $1878 \mathrm{r}$. zaczął starać się o parafię w kościele pobernardyńskim, jednak nim władza świecka w końcu wydała zgodę biskup zmarł. Całą sprawę do końca doprowadził jego następca - bp Wnorowski ${ }^{90}$. Nowa parafia obejmowała swym zasięgiem część ulic Zamojskiej i Bernardyńskiej, ulice wokół kościoła i tę część miasta, która była położona na zachód od kościoła po kapucynach. Ponadto w skład nowej parafii wchodziło przedmieście Piaski, folwarki: Bronowice i Konstantynów, miasteczko Wieniawa i wsie na zachód od Lublina ${ }^{91}$. Porównując ten układ z planem ks. Sosnowskiego z 16 grudnia 1864 r. można stwierdzić, że nowa parafia powstała $\mathrm{w}$ granicach planowanych 20 lat wcześniej parafii - pobernardyńskiej i pokapucyńskiej. Natomiast nowa parafia pod względem terytorialnym była niemal identyczna z projektem delegacji z 20 czerwca 1865 r., z różnicą, że w tamtym planie Piaski, Bronowice i Konstantynów należeć miały do parafii katedralnej. Ostatecznie należy stwierdzić, że plan ks. Sosnowskiego, jak i jego starania dały impuls, aby myśleć o utworzeniu parafii w kościele pobernardyńskim. Mimo, że źródła milczą o jakimkolwiek inspirowaniu się przez bpa Baranowskiego projektem ówczesnego administratora diecezji, to nie można tego wykluczyć.

\footnotetext{
${ }^{86}$ Tamże, Dekret bpa Franciszka Jaczewskiego z 16 października 1902 r.

${ }^{87}$ Kumor-Mielnik, Sieć dekanalna, s. 178; Kumor, Ustrój i organizacja, s. 698.

${ }^{88}$ AAL, sygn. Rep 60 IVB 109, Dekret erekcyjny parafii pw. Nawrócenia św. Pawła w Lublinie z 3 maja 1864 r., k. 56r, 65r.

${ }^{89}$ AAL, sygn. Rep 60 IVB 111, Inwentarz kościoła rzymskokatolickiego parafii pod tytułem Nawrócenia św. Pawła w mieście gubernialnym i powiatowym Lublinie położonego sporządzony 1885, s. 14.

${ }^{90}$ Wadowski, Kościoły, s. 570-571.

${ }^{91}$ AAL, sygn. Rep 60 IVB 109, Dekret erekcyjny parafii pw. Nawrócenia św. Pawła w Lublinie z 3 maja 1864 r., k. 53v, 65v; sygn. Rep 60 IVB 111, Inwentarz kościoła rzymskokatolickiego parafii pod tytułem Nawrócenia św. Pawła w mieście gubernialnym i powiatowym Lublinie położonego sporządzony 1885, s. 16.
} 
W negocjacjach ks. Sosnowskiego z Czerkaskim przewijała się także sprawa kościoła Swiętego Ducha. W ramach uzupełnienia można dodać, że kościół ten po 1866 r. długo pozostawał bez stałej opieki. Władza diecezjalna od czasu do czasu wysyłała tam tylko księdza diecezjalnego, by odprawiał nabożeństwa ${ }^{92}$. Pomysł administratora diecezji, by oddać kościół w opiekę dominikanom musiał pozostać bez odzewu, ponieważ KRSWiD już wcześniej wypowiadała się negatywnie o takiej koncepcji ${ }^{93}$. Ostatecznie z dwóch etatów wikariuszowskich z kościoła pobernardyńskiego jeden przesunięto właśnie do kościoła Świętego Ducha, dzięki czemu odtąd świątynia miała stałą opiekę ${ }^{94}$.

\section{Zakończenie}

Dnia 8 grudnia 1864 r. rozpoczął się blisko dwuletni okres starań o reorganizację życia parafialnego w Lublinie. Wynikał on z potrzeby zapewnienia opieki duszpasterskiej wiernym, po kasacie zakonów w Królestwie Polskim w 1864 r. Bezpośrednim impulsem do podjęcia tej próby była inicjatywa dyrektora KRSWiD Włodzimierza Czerkaskiego wyrosła na akcji zapewnienia obsady w parafiach pozakonnych w miejscowościach poza Lublinem. Mimo, że podjęta próba rozbiła się o nieprzychylność strony rządowej, to ostatecznie należy ocenić, że wysiłki ks. Sosnowskiego nie były daremne. W Lublinie co prawda nie powstały nowe parafie, jednak udało się uzyskać zgodę na przeniesienie nabożeństwa z kościoła św. Mikołaja do świątyni po klasztorze augustianów. Ponadto można przypuszczać, że wysiłki z lat 1864-1866 położyły także pewien fundament pod podzielenie parafii katedralnej i utworzenie parafii w kościele pobernardyńskim, co miało miejsce niemal 20 lat później - w $1884 \mathrm{r}$.

Słowa kluczowe: administrator diecezji, ksiądz Kazimierz Sosnowski, parafia, Lublin, Włodzimierz Czerkaski, kasata zakonów, kościół św. Agnieszki w Lublinie, kościół Nawrócenia św. Pawła w Lublinie, kościół św. Piotra i Pawła w Lublinie

\section{BIBLIOGRAFIA}

\section{Źródla}

Archiwum Archidiecezjalne Lubelskie (AAL) sygn. Rep 60 IVA 32, Akta dotyczące parafii po suprymowanych klasztorach.

sygn. Rep 60 IVB 109, Akta dotyczące kościoła parafialnego Nawrócenia św. Pawła w Lublinie.

sygn. Rep 60 IVB 111, Inwentarz kościoła rzymskokatolickiego parafii pod tytułem Nawrócenia św. Pawła w mieście gubernialnym i powiatowym Lublinie położonego sporządzony 1885 .

\footnotetext{
${ }_{92}$ Wadowski, Kościoły, s. 402.

${ }^{93}$ AAL, sygn. Rep 60 XI 33, List KRSWiD do ks. Sosnowskiego z dnia 7 października 1865 r.

${ }^{94}$ Wadowski, Kościoły, s. 570.
} 
sygn. Rep 60 IVB 126, Fundusze, budowle, cmentarze kościoła filialnego na Czwartku. sygn. Rep 60 IVB 135, Fundusze, budowle, cmentarze Kościoła Parafialnego na Kalinowszczyźnie.

sygn. Rep 60 XI 33, Rozporządzenia dotyczące suprymowanych klasztorów.

Archiwum Państwowe w Lublinie (APL)

sygn. 35/22/0/4.7.1.2/2372, Kapucynów kościoła.

sygn. 35/1861/0/2.4/61, Księga urodzeń, małżeństw i zgonów.

Dziennik Praw Królestwa Polskiego, t. 62, Warszawa 1864.

\section{Opracowania}

Budziarek Marek, Kapucyni w Lublinie. Dzieje klasztoru 1721-1864, Warszawa-Lublin 1996.

Chadam Augustyn, Lublin, w: Klasztory bernardyńskie w Polsce w jej granicach historycznych, red. Hieronim Eugeniusz Wyczawski, Kalwaria Zebrzydowska 1985, s. $188-192$.

Gach Piotr Paweł, Kasaty zakonów na ziemiach dawnej Rzeczypospolitej i Śląska, Lublin 1984.

Gajewski Stanisław, Kasata klasztorów w diecezji lubelskiej w roku 1864, „Roczniki Humanistyczne", 21 (1973) z. 2, s. 351-390.

Jemielity Witold, Język rosyjski w instytucjach kościelnych po powstaniu styczniowym, „Prawo Kanoniczne”, 42 (1999) nr 1-2, s. 209-224.

Kumor Bolesław, Sosnowski Kazimierz Walerian, w: Polski Słownik Biograficzny, t. 40, s. $572-575$.

Kumor Bolesław, Ustrój i organizacja Kościoła polskiego w okresie niewoli narodowej (1772-1918), Kraków 1980.

Kumor-Mielnik Joanna, Sieć dekanalna i parafialna (archi)diecezji lubelskiej w latach 1805-2005, Lublin 2011.

Morawska Klementyna, Centralne władze wyznaniowe Królestwa Polskiego, w: Archiwum Główne Akt Dawnych w Warszawie. Przewodnik po zespole, t. 2, red. F. Ramotowska, Warszawa 1998, s. 177-203.

Okolski Antoni, Wykład prawa administracyjnego oraz prawa administracyjnego obowiązującego w Królestwie Polskim, t. 2, Warszawa 1882.

Prejs Roland, Zakonnicy franciszkańscy Królestwa Polskiego po kasacie 1864 roku. Dzieje - postawy, Warszawa 2003.

Rożek Jakub, Dzieje parafii pw. św. Agnieszki w Lublinie w latach 1866-1939, Lublin 2013 (mps Archiwum KUL).

Smyk Grzegorz, Administracja publiczna Królestwa Polskiego w latach 1864-1915, Lublin 2011.

Starnawski Zbigniew, Kazimierz Sosnowski 1800-1874, administrator diecezji lubelskiej 1863-1869, „Wiadomości Diecezjalne Lubelskie”, 59 (1985), s. 121-124.

Wadowski Jan Ambroży, Kościoły lubelskie, Lublin 2004.

Walewander Edward, Sosnowski Kazimierz, w: Encyklopedia katolicka, t. 18, Lublin 2013, kol. 620.

Wójcik Walenty, Tak zwana reforma klasztorów w 1864 roku na terenie diecezji sandomierskiej, „Archiwa, Biblioteki i Muzea Kościelne”, 23 (1971), s. 343-360.

Zahajkiewicz Marek Tomasz, Centralne urzędy i instytucje diecezjalne, w: Dzieje archidiecezji lubelskiej (1805-2005), red. M. T. Zahajkiewicz, Lublin 2005, s. 51-83. 


\title{
AN ATTEMPT TO REORGANIZE THE STRUCTURE OF THE ROMAN CATHOLIC PARISHES IN LUBLIN IN THE YEARS 1864-1866
}

\begin{abstract}
Summary
The Church performs its task of leading people to salvation, among others, through organizing chaplaincy in parishes. It means that parishes are extremely important centres of each diocese and the community of the faithful. It was the same in Lublin in the 1960s. Due to the fact that there were only two parishes in the city, the pastoral work of diocesan priests was also supported by religious orders. However, the tsarist government, in November 1864, dissolved most of the monasteries in the Kingdom of Poland, which caused difficulties in providing appropriate pastoral care. Therefore, at the end of 1864, the then administrator of the Diocese of Lublin Rev. Kazimierz Sosnowski made an attempt to reorganize a parish life in Lublin in order to satisfy religious needs of the faithful and fill the gap left by the dissolved monasteries. The reorganization involved creating two new parishes in the churches which had belonged to the Capuchins and Bernardines before their dissolution and transferring a parish service from St Nicholas Church to St Agnes Church, which had been in the possession of the Augustinians before the dissolution. In order to conduct this project, Rev. Sosnowski started negotiations with the Government Commission of Internal Affairs and Clergy, which finally ended in 1866. This article details the various stages of these negotiations, their causes and effects.
\end{abstract}

Keywords: the administrator of the Diocese of Lublin Rev. Kazimierz Sosnowski, parish, Lublin, Włodzimierz Czerkaski, the Government Commission of Internal Affairs and Clergy, the dissolution of the monasteries, St Nicholas Church in Lublin, St Agnes Church in Lublin, the Conversion of St. Paul Church in Lublin, Saints Peter and Paul Church in Lublin 